\title{
EXAMINING THE USE OF LAW TO PRESERVE MORALS \\ AND LIVES IN SAME SEX MARRIAGE SITUATION IN NIGERIA
}

\author{
Gloria Faith Ehiemua* \\ http://dx.doi.org/10.4314/og.v16i1.6
}

\begin{abstract}
The law prohibiting Same Sex Marriage in Nigeria is criticised for denying same sex people the right to marry and certain basic freedoms as heterosexuals. Bias against same sex practice is propelled by religious and cultural beliefs on marriage as between opposite sexes. However, perceive threat to continuity and survival of the kinship system furthers non- acceptance of same sex people in society. Although it is widely stipulated that the Nigerian government's decision to criminalise same sex relationships is solely hinged to respect for traditional cum religious values, this work agrees with Mills, Hart and Devlin that, harm to others is the only justifiable ground for limiting rights considered, inalienable to human beings. An objective examination of the Nigerian same sex marriage situation reveals religious intolerance and violent extremism as factors capable of invoking crisis and acts of terrorism in same sex issues as such, the work views the need to protect lives and national security as sufficient grounds for limiting the right to marry and freedom of association between same sex people. Using the duty-rights approach, it shows how several laws which are standards in society can conflict and result in contrasting duties that become a problem for the agent which cannot carry out both duties at the same time. It holds that State's interest to secure national integrity and lives cannot be compromised on the ground of rights.
\end{abstract}

Keywords: Same Sex Marriage, Morality, Rights, Religious Intolerance, Violent Extremism

\section{Introduction}

In modern times, homosexuality -the practice of same sex relationships, gained centre place in discourses on gender, identity and recognition. In Europe and the West, legal battles helped in 
Ehiemua: Examining the use of Law to Preserve ...

securing a wide spread acceptance of same sex practice. However, among nations in Africa, only South Africa legally recognises same sex marriage (Global Legal Research Directorate, 2014. 14). In Nigeria, heterosexuals are of the view that, same sex marriage will not promote growth in a society anchored on the kinship system that centres family ties primarily on blood relations. Thus, 98 percent of Nigerians surveyed, hold the view that homosexuals should not marry (Pew Research Center, 2013). However, the Universal Declaration of Human Rights document empowers homosexuals to demand equal rights and protection against discrimination. As a member of the United Nations, the State has a responsibility to provide, protect, and fulfil human rights but in the case of same sex marriage, the Nigerian government was unable to secure the rights to marry for same sex people for fear that extreme intolerance for same sex relationships can be used as ground for violence and acts of terror by religious extremists.

In 2014, when terrorism was at its peak in Nigeria and there were indications that the battle to liberalise traditional held views on homosexuality was shifting down to Africa, Nigeria passed into law, a bill prohibiting same sex marriage. Survey shows that 87 percent Nigerians regard the law as a welcome development (NOI Polls, 2015). However, the International community with the Lesbian, Gay, Bisexual, Transgender and Intersexual (LGBTI) community, regarded the law as a setback to the struggle for, legal recognition and equality of same sex people. In an appeal to the Nigerian government, the U.S Secretary of State John Kerry, described the decision to proscribe same sex marriage as inconsistent with Nigeria's international legal obligations. In his view, the act undermines democratic reforms and human rights protection (The Guardian, January 2014). Theresa May on the other hand, resounded the need for non discrimination in the enactment of laws (The Vanguard, April 18, 2018). Talks of the law as inconsistent with Nigeria's legal obligation and emphasis on the need not to discriminate, give the impression that the Nigerian government does not have sufficient reason for enacting the law in the first place which projects government act as irresponsible. This work argues that as a member of the United Nations, the Nigerian government is aware of its responsibility to respect, protect and fulfil human rights. 
Therefore, its decision to criminalize same sex marriage and union must have been compelled by an overriding interest. In justifying State's action, this work intends to:

1. establish a connection between the legalization of same sex marriage and Islamic terrorism

2. objectively examine the Nigerian situation on same sex marriage, looking at the remote as well as immediate consequences of legalizing same sex marriage

3. demonstrate the relevance of ethical analysis in conflict situation

\section{Theoretical Framework}

Debates on what the relationship between criminal and moral law should be, is an age-long discussion that is still ongoing. The question of how logical it is to use secular law to enforce morals was examined by Mills who argued against State's use of law to limit human freedom noting that, a limitation to human freedom is only permissible in instances where a conduct is harm causing to others. This view was supported in the 1960's by the Committee on Homosexual Offenses and Prostitution set forth to look into State's regulation of morals using legal means (John Burr and Milton Godinger, 1976. 233). The committee expressed the view that, it is not the function of law to intervene in the private lives of citizens, or seek to enforce any particular pattern of behaviour... and recommended that laws against homosexuality among consenting adults should be eliminated. Devlin drew attention to the fact that there cannot be a strict separation between criminal and moral laws. He observed that "... without shared ideas on politics, morals and ethics no society can exist". His argument is, "if society has the right to make a judgement and has it on the basis that a recognised morality is as necessary to society as, say, a recognised government, then society may use the law to preserve morality in the same way as it uses it to safeguard anything else that is essential to its existence" (Devlin, 1959. 139). This led to a debate between Devlin and Hart. Hart opposes the idea that the society's right to judgement should be based merely on, a "recognised morality" (Dworkin, 1966. 990). He pointed out reasons why a State's right to preservation should be 
Ehiemua: Examining the use of Law to Preserve ...

premised on conditions that are universally acceptable (Beauchamp, 1991. 281-283).

Even though Mills, Devlin and Hart used the non-harm principle to support rights and freedom of homosexuals as far back as the 60's, most societies in Africa, have not recognised the homosexuals' rights and freedom. In short, homosexuality is outlawed in many African countries. African leaders (including Nigeria), use relativist arguments embedded in tradition, religion or culture of their people to defend the use of law in prohibiting homosexuality and denying same sex people, certain rights and freedom. They claim that, homosexuality is unscriptural, unnatural, unprofitable, unhealthy, un-cultural and un-African (Aken'Ova, 2010. 16). However, lack of evidence of harm to others, make out these reasons as insufficient grounds for denying same sex people their basic human rights and freedom.

\section{Methodology}

The work seeks to provide a practical example of how high rate intolerance for an act considered inconsistent with society's shared morality can lead to terrorist acts. The approaches are descriptive, normative and theoretical. It addresses the task by asking the following questions:

1. When does a harmless conduct like homosexuality become a threat to society's shared morality?

2. How does legitimizing same sex marriage pose danger to society's integration 'in Nigeria?

3. Is the threat sufficient in itself, as ground for criminalising same sex relations?

Using the duty-rights ethical theory, it illustrates how conflict can arise from contrasting values and duties to become a problem for the agent who must choose one of two valid claims. Tragically, no matter what choice is made, the agent stands to be judged as having morally failed the party whose claim was dropped. The work contrasts rights, values and duties in its analysis of how valid claims to rights can be overruled by a compelling interest. 


\section{Religious Beliefs and Homosexuality in Nigeria}

Nigeria is an ethnically diverse and multi-religious country. Christianity, Islam and African traditional religion are widely practiced by the people with Christians and Muslims having an almost equal percentage of adherents while the Africa traditional religion has lesser number of people who claim to be adherents. The plurality of religions notwithstanding, it is widely acknowledged that Nigerians are very religious. A recent survey indicates that 93 percent of Nigerians agreed that they are, very religious (Pewresearch, 2017). Therefore, religion influences beliefs on marriage. To most Nigerians, marriage is an institution divinely arranged between a man and woman for the purpose of procreation and companionship. Biblical scripture gives the impression that in the beginning, God ordained marriage between a man (Adam) and woman(Eve) and instructed thus, "therefore shall a man leave his father and mother and shall cleave unto his wife and they shall be one flesh" (Gen 1:28) which projects, an approval of the complementary arrangement.

Christians argue that the story of Lot buttresses God's displeasure over homosexual practices as the cities of Sodom and Gomorrah were completely destroyed because of the act of Sodomy (Homosexuality). Moreover, Leviticus, 20:13 clearly states that, "if a man also lie with mankind, as he lieth with a woman, both of them have committed an abomination: they shall surely be put to death, their blood shall be upon them ..." (KJV). Among Muslims, the Quran tells the story of Lot and shows God's displeasure for homosexuality.

Q7:80-84 reads, "And we sent Lot as a messenger. Remember that he said to his people, "have you become as shameless that you commit such indecent acts as no one has committed before you in the world? You gratify your lust with men instead of women; indeed, you are a people who transgress the limits..." This gives the impression that homosexuality transgresses the norms and is condemned. Africa Traditional Religion intertwines with the culture of the people and holds the view that traditional ways should always be upheld. Adherents believe that marriage is a long standing practice between a man and woman and should be preserved as such for its benefits. To the many religious faithful in Nigeria, 
Ehiemua: Examining the use of Law to Preserve ...

homosexuality is a corruption of God's intention for marriage and mankind.

\section{Contestations and Notions of Homosexuality in Nigeria}

A general notion is that the purpose of marrying is to have children. Therefore, in Nigeria, what defines a man or woman is not just biologically or gender related but essentially, the ability of a man to impregnate a woman and for a woman to get pregnant. As stringent as traditional laws are on adultery, exceptions are allowed for women whose husbands are sterile to have children through other men. The female to female marriages practised in some parts of Nigeria, in the past helped women who are barren or unable to have a male child in achieving their desire. A man to man or woman to woman relationship cannot on its own produce children as such it is regarded as incompatible with the African system and unfit to uphold African values and traditions. It is argued that, same sex marriage is a threat to the structure of the society.

\section{The Structure of Society}

The structure of the Nigerian society is based on the kinship system that is dependent on marriage and children for survival. Africans value for children and a large family connected by blood and marriage is used to promote society's continuity. In the past, economic activities such as farming and trading depended on children to provide sufficient hands. Therefore, social and economic prosperity was tied to having large number of children and wives. In which case, the family played central role in the advancement of society. It is understandable then, that sexual preference for same gender would elicit fear for society's flourishing and continuity. Labelling of homosexuality as unproductive in society has to do with its inability to contribute to society's survival and continuity.

\section{The Sacred System}

Nigerians argue that accepting same sex practice mean restructuring an age long arrangement that has worked for the people. Many traditional practices of religious importance are woven children who are expected to actively participate. For instance, custom requires children of a dead person to perform certain funeral rites and burial 
ceremony in order to ease the dead person's journey to the other world and facilitate his/her entrance and acceptance into the world of ancestors. In some cultures, in Igbo land for instance the first son or daughter is expected to perform the ritual washing of the dead man or woman respectively (Kanu, n.d) Performing burial rites enables children to inherit their dead parents.

\section{Lineage Continuity}

The notion of same sex practice as Un-African has its root in the traditional beliefs and practices of the people that support childbearing. Most Africans regard marriage as the means through which the family lineage is increased and expanded. Accordingly, Mbiti(1968) observes that, people are members of the larger community and a particular family when they can trace their genealogy and lineage to the community or family. Not having children poses threat to lineage continuity practice among Africans.

\section{Ancestral Belief}

Africans believe that there is a spirit world where their dead fathers and forebears dwell. It is said that unless a person has close relatives to remember him/her when one is physically dead, then he/ she is nobody and simple vanishes like a flame when it is extinguished (Mbiti 1968).Children keep the memories of their loved ones alive through ancestral worship

\section{Belief in Reincarnation}

Forebears have the opportunity of coming back to relive life and correct mistakes of past life, or show their affection for a particular child that took good care of them in their past life through their genealogical children. Africans look forward to another chance given by reincarnation to correct certain injustice done to them or achieve that which they were unable to accomplish before they died. Reincarnation had helped the poor, deprived, and oppressed to build hope on a better future and destiny in the next life. Because the nature of Homosexuality is such that cannot fit into the operation of the kinship system and the sacred order meant to preserve the structure of society, it is regarded as unproductive 
Ehiemua: Examining the use of Law to Preserve ...

\section{Modernisation and the Paradigm Shift}

Traditional ways of doing things shifted with changes in systems pertaining, leadership, economy and rationalisation. The introduction of democratic leadership and capitalist economy broadened knowledge and outlook of "who is productive" in society. With the replacement of traditional farming implements with machineries, the need for many working hands reduced. Urbanisation opened up opportunities to white collar jobs in cities and education was prioritised. Farming which in the past was the main source of livelihood, was abandoned for education that was made available to all regardless of sexuality. Resulting from the acquisition of knowledge, emphasis on many children was watered down while economies grew and societies advanced based on intellectual power not, biological or physical strength.

At this point, the difference between the heterosexual and homosexual's contribution to society's flourishing thinned out, as both homosexuals and heterosexuals became of equal importance tothe economic wellbeing of society. Equality in sexuality was furthered enhanced by a democratic system that supports equal participation in politics. Thus, political and economic systems operated in the modern world make homosexuals relevant in society and raises question on the rationality behind the notion of homosexuality as, "unproductive" and "unfit" for society's flourishing.

\section{Sexual Rights and Same Sex Marriage (Prohibition) Act}

Human rights are universal values enshrined in the Universal Declaration of Human Rights document as inalienable, fundamental rights which everyone is entitled to regardless of nationality, location, religion, sex or any other status. The principle of equality and non discrimination are central to human rights law and are recognised as norms of jus cogens (Office of the United Nations High Commissioner for Human Rights, Fact Sheet No.32). The doctrine of natural rights give rise to the notion that there is a private sphere within which the activities of the individual or at least, those of his activities which do not affect the security of the equal rights of others should be immune to public inquiry or public control (Encyclopedia.com) and empowers homosexuals to demand for a 
society, free from discrimination on the basis of their sexuality. Sexual rights embrace certain human rights that are already recognised in international and regional human rights documents and in national laws (European Humanist Federation, 2015). It includes the rights of everyone to decide freely and responsibly on all aspects of their sexuality, to be free from discrimination, coercion or violence in their sexual lives and sexual decisions, to expect equality, mutual respect and full consent in sexual relationships (European Humanist Federation, 2015).

Legal victories gained by gay bodies and supporters in most parts of Europe and United Nations encouraged increased activities in the struggle for same sex rights in Africa. In 2011, the Obama administration made the promotion of gay rights an integral part of American foreign policy. Report states that since then, it has pushed for the decriminalisation of homosexuality overseas, working with the United Nations (Norimitsu, New York Times. Dec.2015). As at 2015, the American government had spent more than \$41 million specifically to promote gay rights globally, along with a portion of $\$ 700$ million earmarked for marginalised groups to support gay communities and causes. More than half of the $\$ 700$ million, and 6.6 million of the $\$ 41$ million was spent on sub-Saharan Africa" (Norimitsu, Dec.2015). Report indicates that many private supporters of equal rights for gay people in the United Nations are increasing their funding of gay causes abroad, especially in Africa (Norimitsu, Dec. 2015)

There was a setback in the fight for the rights of same sex people when the same sex marriage (prohibition)came into law in January 2014. This Law criminalised the same sex relationships. It contains penalties of up to 14 years in prison and bans same sex marriage and unions alongside membership of same sex rights groups. The Bill for an Act criminalising same sex marriage was first proposed in 2006, by a former President of Nigeria, Olusegun Obasanjo. In his defence of the proposed Bill, he stated that "homosexuality is unnatural, ungodly and un-African (Aken'Ova, 2010). Accordingly, the Bill against same sex marriage was to "check the excesses of a group of young people whose behaviour has become increasingly embarrassing" (The Nordic African Institute, 2017) The former Anglican Primate, Peter Akinola argued against 
Ehiemua: Examining the use of Law to Preserve ...

same sex marriage in the same vein as the former President, adding that "...Same sex marriage is a perversion, a deviation and an aberration that is capable of engendering moral and social holocaust". He further stated that "outlawing it is to ensure the continued existence of this nation" (Aken'Ova, 2010). Although these statements are similar, reference to "engendering moral and social holocaust" makes a remarkable difference. It is agreed, that intolerance to conduct considered inconsistent with society's morality is inadequate for using legal means to prohibit such conduct. However, Devlin observed that, "a real feeling of reprobation" calls for caution when introducing new Laws (Devlin, 1959.143)

\section{Assessing Arguments in the Use of Law to Prohibit Same Sex Marriage in Nigeria Using the Harm Principle}

Based on arguments put forth by heterosexuals and their leaders in Nigeria, homosexuals and their supporters argue that opposition to their right to marriage is embedded in tradition, religion and culture. They align argument of homosexuality as "un-African" to "homophobic sentiments" implying that such arguments only project fear of same sexuality which is not a justifiable ground for criminalising same sex relationships. They hold the views that violate against same sex rights are exacerbated by the law that criminalises same sex relationships. To highlight the harmless nature of homosexuality, the LGBTI community and their supporters question why a private conduct between two consenting adults is criminalised. Drawing attention to homosexuals as,law abiding citizens Therein, they make a demand on government to act responsibly by ensuring that the rights of same sex people are protected. They also appeal to the international community to live up to its responsibility by making countries that criminalise same sex relationships repel the law.

According to Mills, the only acceptable reason for limiting human rights and freedom is a ground of harm to others. The Wolfenden committee support Mill's view that argument to preserve morals is insufficient for limiting rights and freedom since morality, changes from generation to generation. Hart on the other hand, disagrees with Devlin support for cultural relativism noting that 
certain cultural practices violates the humanity of others. Devlin however, made a significant observation about "the extent to which society will tolerate departures from moral standards"(Devlin, 1958.142). In Devlin's view, the use of law to protect morality should be situational. As Fletcher puts it, "the only reason for disapproving sexual relations would be situational not lead or principled. It would be because the circumstances realistically and imaginatively weighed, with a responsible eye on remote as well as immediate consequences, balance out against the liaison than for it" (Fletcher, 39). The government's arguments for the use of law in preserving morals are based on cultural and moral sentiments which make it out as, selective, partial or discriminatory. Discrimination of sexuality is contrary to the government's international obligation to promote and protect equal rights of all human beings regardless of sexuality. On the strength of this, government is liable to violating human rights. Arguments of same sex as "un- African" or against the dictates of shared morality are not compelling enough to override the rights of same sex people to equality and non-discrimination. The Ultimate ratio, that is, the outside chance that what the law forbids can be excused in this situation, lies in the proof that extreme intolerance of a conduct considered inconsistent with society's shared morality is capable of resulting to loss of lives or damage to national safety.

\section{Radicalisation and Extremist Violence}

In Nigeria, support for government's decision to criminalise same sex marriage can be drawn from factors that are psychologically, strategically and ideologically related to religious terrorism and extremism. Nigeria is one of the countries in Asia and Africa where Muslims have an overall majority. However, in recent times, it has been face with challenges from Islamic terrorist groups that clamour for severance of Islamic nations with western institutions or for globalisation of Islamic value. These groups accuse some governments in Africa as acting as stooges to the West and seek opportunity to replace them. The Global Terrorism Index (2015. 14) states that two countries, Iraq and Nigeria host the deadliest terrorist groups. From 2009, Boko Haram an Islamic set that is also referred to as Jama'atu Ahlis Sunna Lidda'awati Wal-Jihad, wages war 
Ehiemua: Examining the use of Law to Preserve ...

against corrupt false Muslims in politics as well as the Federal Republic of Nigeria (United States Institute of Peace Special Report, 2018).

The ideology of Boko Haram is twofold; opposition to democracy and rejection of western style (Alex Thurston, 2016). Although, Boko Haram means, "Western education is forbidden," the rejection of western education goes beyond education to social and political ills allegedly resulting from western domination. In 2010 Shekau made a jihad declaration against Nigeria and the United States. However, Nigeria had been mapped out earlier than 2010 by the Muslim world as a region of priority for jihad because of what they referred to as, "the readiness of their people to accept the initiative of jihad, the weakness of their ruling regimes and the existence of the history of jihadi expedition" (Zenn etal, 2018). Report reveals that Boko Haram does not have a sophisticated financing structure (fact sheet on terrorism, 2016) but works towards establishing an Islamic state in Nigeria which is rich in oil and blessed with abundant human and natural resources that can boost its financial position and activities.

The term radicalisation is often used by experts when discussing Salafists, the ultra-conservative Islamists who are known for aggressive proselytising and their sympathies for ISIS and AlQaeda. In early 2001, Osama bin Laden specifically urged the Muslims of Nigeria, as well as of other West Africa states, to rise up against what he called, U.S "enslavement" which marked the beginning of an African Jihad (Bodansky, 2015). In June 2010, Boko Haram became formally associated with the global jihad via the regional entity Al- Qaidat Jihad fi al-Maghreb al-Islami whose leader stressed the entire global jihad movement commitment to expanding presence and operation in sub-Saharan Africa noting that (Africa) provides for strategic depth that would give (jihadists) a bigger scope for manoeuvres (Bodansky, 2015). Accordingly, Shekau the leader of Boko Haram "captivates his followers by combining his Salafi religious interpretation with the victimhood that some Muslims perceive around the world." (Zenn et al, 2018).

Narratives of same sex marriage as, imposition of foreign values and culture do not only contribute to acceptance of same sex marriage as un-African but also, create the impression of a stronger nation 
preying on a weaker country withthe media deepening the "us against them" divide with references to the struggle for same sex recognition and inclusion in Africa as, "cultural battle between the West and Africa" (Nomiritsu, Dec.2015). One of the most important issues in jihadist religiosity is that of Farqa enadjia -the chosen group (Berger et.al, 2008). Shekau had announced since 2009 that Boko Haram was ready to launch attacks on "Western Culture" in Nigeria (Bodansky, 2015). To extremists, jihad is more of a means of returning order. Therefore, when political and religious institutions are no longer capable of providing both citizens and believers with the means to resolve contradictions inherent in the hyper-liberal context in which they evolve, jihadists may come in as self-acclaimed saviours.

\section{Citizenry and Government Responsibilities}

Culture and religion are important means of self-identity that also form the basis for radicalisation. In Nigeria, most people are not happy with the West and the claim that homosexuality is a natural rights issue because of what is perceived as, a threat to continuity and survival of Nigerians as a people with their own values and beliefs. Same sex marriage opposes values that are dear to Nigerians therefore, legalising it might trigger crisis and acts of terrorists. It is estimated that terror groups have killed over 30,000 people in Nigeria since 2003, causing the displacement of more than 2.4 million people (ISS, 2020).

The right to life is a supreme right without which, the effective guarantee of all other human rights would be without meaning (factsheet.no 32). Even though the government is obliged to the protection of the rights of same sex people, it also has a right and duty to protect all lives under its jurisdiction which violent extremism poses danger to. Under no circumstances is derogation from the right to life permitted. International Human Rights conventions provide that States may legitimately limit the exercise of certain rights including the right to respect for one's private and family life (factsheet.no 32) which is the basis for same sex people's agitation against government.

The UN Security Resolution 1624 (2005) out of deep concern that incitement of terrorist acts motivated by extremism and 
Ehiemua: Examining the use of Law to Preserve ...

intolerance poses serious and growing danger to the enjoyment of human rights"(Yoel, 2010. 648) call on States to adopt such measures, as may be necessary, appropriate and in accordance with their obligations under international law to prevent acts of terrorism. However, the Nigerian government cannot rise up to the call to protect States from terror attacks and preserve lives within its territory, if it does not prohibit the act of incitement using law. Unfortunately, prohibiting the act of incitement which in this case is, same sex marriage would entail a limitation to the of same sex people. Thus, government's interest to secure state safety and lives compelled it to prohibit same sex relationships. Mitigating terrorism or terrorists act through prevention is an agreed best practice to violent extremism or terrorism.

\section{Conclusion}

For so long, rulings in favour of the elimination of laws criminalising same sex relations have been hinged to the nature of homosexuality as harmless and incapable of causing danger to society's integrity. Therefore, on the ground of insufficient evidence of harm to society, same sex battles for equality have been fought without recourse of its appropriateness to society's circumstances or situation. However, there are indications that in Nigeria, legitimizing same sex marriage is regarded as an imposition on a majority whose value system is dependent on children for survival. The fear of damage to values on which a society is built takes a turn for the worst with the presence of terrorist groups whose ideology is laid on a religious foundation that rejects homosexuality. Therein, moving contestations against same sex relationships beyond reactions of disgust for same sex practice to strong disapproval that spurs violent reaction from extremists, in order to protect lives and prevent society from disintegrating, the State mitigated incitement to terrorists' acts by prohibiting same sex relationships. It is important to state here that, as legal battles for same sex rights and freedoms shift base in the $21^{\text {st }}$ century to Africa, there is need to be cautious in introducing new laws because of the peculiar situation of some African countries.

\section{*Gloria Faith Ehiemua, PhD}

Department of Religions, University of Benin

Edo State, Nigeria

Email: fehiemua@gmail.com 


\section{References}

Aken'Ova Dorothy. 2010 “State-Sponsored Homophobia: Experiences from Nigeria" in Heinrich Boll Striftung, Perspectives: Struggle for Equality, Sexual Orientation, Gender Identity and Human Rights in Africa

Alex, Thurston. 2016. "The Disease is Unbelief: Boko Haram Religious and Political Worldview" The Brookings Project on US Relation with the Islamic World, Analysis Paper. http://www.brooking.edu

Boubekeur Amel. 2018 "The Religious and Ideological Factors of Violent Extremism" IEMED

Burt, Robert A. 2004. "Moral Offenses and Same Sex Relations: Revisiting the Hart - Devlin Debate" Faculty Scholarship Series. 711. http//digitalcommons.law.yale.edu/fsl_papers711

Corcoba, J., Portilla, R. (2019), "Prediction Model of Propaganda Characteristics used by Main Jihadist Groups," Journal of Aggression, Conflict and Peace Research, vol.11 No.1, p.59-66. https/doi.org/10.1108/JACPR-04-2018-0355

Denise C.T, Peterfreund S.P, White N.P. 1996. Great Traditions in Ethics. Eighth Edition. Wadsworth Publishing Company

Dworkin, Ronald M., 1966. "Lord Devlin and the Enforcement of Morals" FacultyScholarship Series. 3611. https://digitalcommons.law.yale.edufss_papers/3611

European Humanist Federation. 2015, "What are Sexual and Reproductive Health and Rights"

Fletcher Joseph, Moral Responsibility: Situation Ethics at Work. The Westminister Press

Heinrich Boll Stiftung (2010), Perspectives: Struggle for Equality, Sexual Orientation, Gender Identity and Human Rights in Africa

John Burr, Milton Godinger. 1976. Philosophy and Contemporary Issues. Macmillian Publishing Company

Kanu I. A. A Hermeneutic Approach to African Traditional Religion, Theology and Philosophy. Aba. 
Ehiemua: Examining the use of Law to Preserve ...

Mannik Erik, 2011. "Terrorism: its Past, Present and Future Prospects" www.ksk.edu.e>2011/03>KVUOA_Toimetised_12_Mannik

Mbiti J. 1968. African Religions and Philosophy. Narobi, East African Educational.

NOI POLLS. 2013. “About Anti-Same Sex Marriage Bill” http://www.noipolls.com

NOI POLLS. 2015 "Gay Rights: Perception of Nigerians on LGBT Rights Poll Report,” https://www.noi.polls.com

Norimitsu Onishi. "U.S Support of Gay Rights in Africa May Have Done More Harm than Good.” New York Times, Dec.20, 2015

Office of the United Nations High Commissioner for Human Rights. "Human Rights, Terrorism and Counter-terrorism." Fact Sheet No.32

OSCE/ODIHR, 2006."Human Rights Consideration in Combating Incitement to Terrorism and Related Offences"

Pew Research Centre, "The Global Divide on Homosexuality". June 4, 2013. pewglobal.org/2013/06/04

The Guardian. 2014. "Nigeria's President Signs Law Imposing up to 14 years Jail for Gay Relationships". The Guardian Jan 13, 2014 www.theguardian.com

The Nordic Africa Institute, 2017, "Homosexuality is still Taboo in many African Countries" the Nordic Africa Institute retrieved from nai.uu.se

TUGWEL M. 1986, “Terrorism and Propaganda: Problem and Response". Conflict Quarterly

Yael Roen, "Incitement to Terrorist Acts and the International Law." Leiden Journal of International Law. 23(03): 645-674 September, 2010. DOI:10.1017/S09215650269

Zenn, Jacob (Ed.). 2018. Boko Haram Beyond the Headlines: Analyses of Africa's Enduring Insurgency. Combating Terrorism Center United States Military, Department of Defense of US Government. May 2018 Academy https://ctc.usma.edu 